\title{
JIMMBA
}

Jurnal IImiah Mahasiswa Manajemen, Bisnis dan Akuntansi

Homepage: http://journal.stieputrabangsa.ac.id/index.php/jimmba/index

\section{Pengaruh Kesempatan Investasi, Leverage, dan Likuiditas Terhadap Kebijakan Dividen pada Perusahaan yang Terindex di JII Periode 2015-2018}

\author{
Vinna Rahma Putri ${ }^{1}$, Aris Susetyo ${ }^{2}$ \\ ${ }^{1}$ Sekolah Tinggi Ilmu Ekonomi Putra Bangsa \\ 2Sekolah Tinggi Ilmu Ekonomi Putra Bangsa \\ Email: vivinarahma69@gmail.com
}

\section{ARTICLE INFO}

Article History:

Received: July $6^{\text {th }} 2020$

Accepted: August 19th 2020

Published: August 31 2020

Keywords: Dividend Policy, Investment Opportunity, Leverage, Liquidity

\begin{abstract}
Dividend policy determines the distribution of profits between payments to shareholders or corporate reinvestment. The precentage of profits paid to shareholders as cash dividends is the DPR (Dividend Pyout Ratio). This study was conducte to examine the effect of the variable investment opportunity, leverage, and liquidity on dividend policy in companies indexed in JII in the period of 20152018. The population in this study were 48 companies and the purpossive sampling method obtained 44 observations. The analysis shows that leverage and liquidity have a negative effect on dividend policy while investment opportunities have no influence on dividend policy. The adjusted $R$ Square value is 0,601. This means that $60,1 \%$ of the diividend policy is influenced by investment opportunity, leverage, and liquidity variables; while the remaining $39,9 \%$ is influenced by other variables not examined in this study.
\end{abstract}

\section{Pendahuluan}

Peran pasar modal dalam perekonomian sangat erat kaitanya dengan hubungan antara perusahaan sebagai sarana permintaan modal dengan investor atau pemilik modal. Hubungan antar keduanya sama - sama mendapatkan keuntungan dalam proses interaksi yang dilakukan di dalam pasar modal, sehingga pasar modal dapat terus berkembang. Mayoritas penduduk di Indonesia beragama Islam, sehingga banyak investor di Indonesia yang menanamkan modalnya di pasar modal yang berbasis syari' ah. Menurut Abdalloh (2018 : 19), pasar modal islam atau pasar modal syari'ah adalah seluruh aktivitas di pasar modal yang memenuhi prinsip - prinsip islam. Indeks pasar modal syariah di Indonesia salah satunya yaitu Jakarta Islamic Index (JII). JII merupakan indeks syariah yang pertama kali 
diluncurkan dari hasil kerjasama anatara Bursa Efek Indonesia dengan PT Danareksa Investment Management di pasar modal Indonesia pada tanggal 3 Juli 2000. Bursa efek Indonesia menentukan dan melakukan pemilihan emiten syariah yang menjadi konstituen JII. Tujuan dibentuknya JII yaitu untuk dijadikan sebagai usaha untuk meningktkan investasi para investor di pasar modal syariah.

Perkembangan bisnis di pasar modal syari'ah yang sangat pesat dibutuhkan ketepatan dalam mengambil keputusan, yang harus diperhatikan dan dipertimbangkan oleh pihak manajemen perusahaan. Menurut Arilaha (2009) kebijakan dividen suatu perusahaan melibatkan dua pihak yang saling bertentangan, yaitu kepentingan para pemegang saham yang mengharapkan dividen dengan kepentingan perusahaan terhadap laba ditahan. Kesempatan investasi atau investment opputrunity set merupakan komponen dari niai perusahaan dan hasil pilihan dari membuat keputusan investasi dimasa yang akan datang.

Kesempatan investasi bertujuan untuk meningkatkan pertumbuhan perusahaan menggunakan dana yang berasal dari sumber dana internal untuk membiayai kegiatan reinvestasi karena data tersebut memiliki risiko dan dana yang lebih rendah. Menurut Sartono (2001 : 293), salah satu faktor yang mempengaruhi kebijakan dividen ialah rasio likuiditas. Rasio likuiditas (liquidity ratio) merupakan rasio yang menggambarkan kemampuan perusahaan memenuhi kewajiban (utang) jangka pendeknya. Likuiditas mempunyai hubungan yang searah dengan kebijakan dividen. Rasio leverage atau rasio solvabilitas, merupakan rasio yang digunakan untuk mengukur sejauh mana aktiva perusahaan dibiayai dengan utang. Artinya, beberapa besar beban utang yang ditanggung perusahaan dibandingkan dengan aktivanya.

Rata-rata rasio kebijakan dividen yang di proxy-kan sebagai dividend payout ratio (DPR) pada 11 perusahaan yang tercatat di JII yang konsisten membagi dividenya selama periode 2015 sampai dengan 2018 menunjukkan hasil yang tidak konsisten namun cenderung meningkat pada tiga tahun terkahir periode. Rata - rata leverage yang dihitung dengan menggunakan Debt to Equity Ratio (DER) pada tahun 2015 - 2016 mengalami penurunan signifikan sebesar $11,82 \%$ serta diikuti penurunan rasio kebijakan dividen yang dihitung menggunakan DPR (Dividend Payout Ratio) sebesar 6,28\%. Hal tersebut tidak sesuai dengan teori leverage yang berpengaruh negatif terhadap kebijakan dividen bahwa jika utang perusahaan semakin meningkat maka kemampuan perusahaan untuk membayar dividen kepada pemegang saham akan semakin menurun ( Hery, 2017 : 57). Tingkat likuiditas perusahaan yang konsisten di JII selama periode 2015-2018 cenderung mengalami penurunan dari tahun 2016 sampai dengan tahun 2018. Pada tahun 2016 rasio likuiditas mengalami peningkatan dengan presentase sebesar 184,94\% namun tidak diikuti dengan kenaikan rasio kebijakan dividen, penurunan DPR ditahun 2016 dengan presentase sebesar 47,74\%. Menurut Sartono (2001 : 293) likuiditas mempunyai hubungan yang searah dengan kebijakan dividen, semakin besar likuiditas suatu perusahaan maka akan semakin besar pula kemampuan perusahaan dalam membayarkan dividennya. 


\section{Kajian Teori dan Telaah Literatur}

\section{Teori Keagenan}

Teori kegaenan (Agency Theory) merupakan basis teori yang mendasari praktik bisnis perusahaan yang dipakai selama ini. Teori keagenan mendasarkan hubungan kontrak antara investor dan manajemen. Seseorang atau beberapa investor (principal) memperkerjakan orang lain sebagai manajemen (agen) dalam suatu perusahaan untuk melaksanakan wewenang yang telah dibuat. Akibat dari kondisi tersebut memicu adanya konflik antara kedua pihak, dikarenakan adanya perbedaan kepentingan yang akan timbul dalam kondisi itu (agency problem). Teori keagenan ini berusaha untuk menyelesakan masalah - masalah yang berkaitan dengan agency problem, yaitu :

a. Masalah pengawasan (monitoring) yang timbul karena pemegang saham tidak dapat membuktikan apakah manajemen (agen) telah berperilaku secara tepat;

b. Masalah pembagian risiko (risk sharing) khususya dalam kasus pengendalian outcome yang timbul ketika pemegang saham dan manajemen bersikap berbeda mengenai risiko.

\section{Kesempatan Investasi}

Menurut Myers dalam Natalia (2010 : 9) Investment Opportunity Set (IOS) merupakan nilai perusahaan yang besarnya tergantung pada pengeluaran-pengeluaran yang ditetapkan manajemen dimasa yang akan datang, yang pada saat ini merupakan pilihan-pilihan investasi yang diharapkan akan menghasilkan return yang lebih besar. Oleh karena itu, Investment Opportunity Set (IOS) adalah komponen-komponen dari nilai perusahaan dan merupakan hasil dari pilihan-pilihan untuk membuat keputusan investasi dimasa yang akan datang.

Opsi investasi dimasa yang akan datang tidak semata-mata hanya ditunjukkan dengan adanya proyek-proyek yang didukung oleh kegiatan riset dan pengembangan saja, tetapi kemampuan perusahaan yang lebih dalam mengeksploitasi kesempatan mengambil keuntungan dibandingkan dengan perusahaan lain. Pilihan-pilihan investasi atau pertumbuhan bagi suatu perusahaan merupakan sesuatu yang secara melekat bersifat tidak dapat diobservasi.

\section{Leverage}

Menurut ( Kasmir, 2010 : 112) bahwa rasio leverage atau rasio solvabilitas, merupakan rasio yang digunakan untuk mengukur sejauh mana aktiva perusahaan dibiayai dengan utang. Artinya, beberapa besar beban utang yang ditanggung perusahaan dibandingkan dengan aktivanya. Dalam arti luas dikatakan bahwa rasio solvabilitas digunakan untuk mengukur kemampuan perusahaan untuk membayar seluruh kewajibannya baik jangka pendek maupun jangka panjang apabila perusahaan dibubarkan (dilikuidasi). Adapun jenis-jenis rasio solvabilitas antara lain :

\section{Debt to Asset Ratio atau Debt Ratio}

2. Debt to Equity Ratio

3. Long Term Debt to Equity Ratio

4. Times Interest Earned

5. Fixed Change Coverage 


\section{Likuiditas}

Menurut Fred Watson dalam Kasmir (2010 : 110) menyebutkan bahwa rasio likuiditas (liquidity ratio) merupakan rasio yang menggambarkan kemampuan perusahaan memenuhi kewajiban (utang) jangka pendek. Artinya apabila perusahaan ditagih, maka akan mampu untuk memenuhi utang (membayar) tersebut terutama utang yang sudah jatuh tempo. Jenisjenis rasio likuiditas yang dapat digunakan terdiri dari :

1. Rasio Lancar

2. Rasio sangat Lancar

3. Rasio Kas

4. Rasio Perputaran Kas

5. Inventory to net working capital

\section{Dividen}

Menurut Salim (2010 : 38) dividen merupakan pembagian sebagian keuntungan yang diperoleh perusahaan kepada para pemilik saham sesuai dengan presentase kepemilikannya. Ada atau tidak adanya dividen ini ditentukan oleh pihak manajemen. Ketika perusahaan mendapatkan keuntungan, ada dua hal yang mungkin terjadi, yaitu pihak manajemen akan membagikan sebagian keuntungan tersebut kepada pemilik saham dan kemungkinan kedua adalah laba tersebut akan ditahan dan tidak dibagikan kepada pemilik saham dengan alasan perusahaan akan melakukan ekspansi usaha.

\section{Kebijakan Dividen}

Menurut Riyanto (2001 : 265), kebijakan dividen adalah hal yang bersangkutan dengan penentuan pembagian pendapatan (earnings) antara penggunaan pendapatan untuk dibayarkan kepada para pemegang saham sebagai dividen atau untuk digunakan didalam perusahaan yang berarti pendapatan tersebut harus ditahan didalam perusahaan sebagai bentuk laba ditahan. Laba ditahan (retained earnings) merupakan salah satu sumber dana paling penting untuk membiayai pertumbuhan perusahaan, tetapi dividen merupakan arus kas yang disishkan untuk pemegang saham. Kebijakan dividen ini memiliki dua karakteristik yaitu Dividen Payout Ratio (DPR) dan Stabilitas dividen dari waktu ke waktu.

Menurut Gito dan Basri (2002 : 232), Dividen Payout Ratio (DPR) adalah perbandingan antara dividen yang dibayarkan dengan laba bersih yang didapatkan dan biasanya disajikan dalam bentuk presentase. Semakin tinggi dividend payout ratio akan menguntungkan para investor tetapi dari pihak perusahaan akan memperlemah internal financial karena memperkecil laba ditaan. Tetapi sebaliknya dividend payout ratio semakin kecil akan merugikan para pemegang saham (investor) tetapi internal financial perusahaan semakin kuat.

Stabilitas dividen merupakan pembayaran dividen yang stabil dalam jangka waktu yang lama, sedang kebalikannya adalah pembayaran dividen yang sesuai dengan presentase tetap perusahaan. Dividen yang stabil dapat menyampaikan pandangan manajerial bahwa dalam jangka panjang perusahaan akan menjadi lebih baik dari kondisis saat pendapatan turun. Jadi, manajemen mampu mempengaruhi para investor melalui kadar informasi dari dividen. Para investor yang menghendaki pendapatan periodik akan menyukai perusahaan dengan dividen 
stabil daripada perusahaan yang dividenya tidak stabil, meskipun dua perusahaan tersebut mempunyai pola yang sama dari pendapatan dan dividend payout ratio jangka panjang.

\section{Hipotesis}

Hipotesis dalam penelitian ini :

$\mathrm{H}_{1}$ : Kesempatan investasi berpengaruh negatif terhadap kebijakan dividen

$\mathrm{H}_{2}$ : Leverage berpengaruh negatif terhadap kebijakan dividen

$\mathrm{H}_{3}$ : Likuiditas berpengaruh positif terhadap kebijakan dividen

\section{Metode Penelitian}

\section{Populasi dan Sampel}

Dalam penelitian ini yang menjadi populasi adalah perusahaan yang tercatat di Jakarta Islamic Index pada tahun 2015 sampai dengan tahun 2018 sebanyak 30 perusahaan. Menurut Sugiyono (2010:116) sampel adalah bagian dari jumlah dan karakteristik yang dimiliki oleh populasi tersebut. Jumlah sampel dalam penelitian ini adalah 11 perusahan.

\section{Teknik Pengambilan Sampel}

Teknik pengambilan sampel dalam penelitian ini menggunakan purposive sampling yaitu teknik pengambilan sampel berdasarkan pertimbangan atau kriteria tertentu. Adapun kriteria pengambilan sampel adalah sebagai berikut :

1. Perusahaan yang konsisten tergabung dalam index JII dari tahun 2015 sampai dengan tahun 2018.

2. Perusahaan yang konsisten dalam membagi dividen dari tahun 2015 sampai dengan tahun 2018.

\section{Definisi Operasional Variabel}

1. Kesempatan Investasi

Variabel kesempatan investasi dalam penelitian ini dihitung dalam rumus sebagai berikut

2. Leverage

$$
\text { CAPBVA }=\frac{\text { Nilai buku AT }(t)-\text { Nilai Buku AT }(t-1)}{\text { Total Aset }}
$$

Dalam penelitian ini, leverage diproxykan-kan dalam Debt to Equity Ratio merupakan rasio yang digunakan untuk menilai utang dengan ekuitas. Untuk mencari rasio ini dengan cara membandingkan antara seluruh utang, termasuk utang lancar dengan seluruh ekuitas.

3. Likuiditas

$$
\text { Debt to Equity Ratio }=\frac{\text { Total Utang }(\text { Debt })}{\text { Ekuitas }(\text { Equity })}
$$

Dalam penelitian ini, likuiditas diproxykan-kan dalam rasio lancar atau current ratio, merupakan rasio untuk mengukur kemampuan perusahaan membayar kewajiban jangka pendek atau utang yang segera jatuh tempo pada saat ditagih secara keseluruhan. Rasio lancar dapat pula dikatakan sebagai bentuk untuk mengukur tingkat keamanan (margin of safety) suatu perusahaan.

$$
\text { Current Ratio }=\frac{\text { Aktiva Lancar }(\text { Current Assets })}{\text { Utang Lancar }(\text { Current Liabilities })}
$$


4. Kebijakan Dividen

Variabel kebijakan dividen dalam penelitian ini diproxy-kan dalam rumus DPR (dividend payout ratio) sebagai berikut :

$$
\text { Dividend Payout Ratio }(D P R)=\frac{\text { Total dividen per saham }}{\text { Laba per saham }}
$$

\section{Hasil dan Pembahasan}

\section{Analisis Regresi Berganda}

Sampel dalam penelitian ini yaitu perusahaan yang konsisten di JII sebanyak 11 perusahaan dalam kurun waktu 2015-2018, sehingga berjumlah 44. Namun, karena ada beberapa data outliers yang menyebabkan data tidak normal maka data outliers tersebut dihapus, sehingga data yang diolah berjumlah 34 .

Tabel 1. Statistik Deskriptif

\begin{tabular}{lrrrrr}
\hline \multicolumn{5}{c}{ Descriptive Statistics } \\
\hline & N & Minimum & Maximum & Mean & $\begin{array}{c}\text { Std. } \\
\text { Deviation }\end{array}$ \\
\hline Kesempatan_Investasi & 34 & $-35,01$ & $2,83 \mathrm{E}-13$ & $-24,7894$ & 6,86321 \\
Leverage & 34 & $-1,69$ &, 98 &,- 2063 &, 66332 \\
Likuiditas & 34 &,- 50 & 1,54 &, 4507 &, 53626 \\
Kebijakan_Dividen & 34 & 3,41 & 4,60 & 4,0880 &, 28471 \\
Valid N (listwise) & 34 & & & & \\
\hline
\end{tabular}

Sumber data : Hasil olah data SPPS, 2020

Variabel kesempatan investasi yang diproksikan dengan CAPBVA memiliki rata-rata sebesar $-24,7894$ dengan standar deviasi 6,86321. Kesempatan investasi tertinggi (maksimum) adalah 2,83E-13, sedangkan nilai terendah (minimum) sebesar -35,01. Leverage yang dihitung dengan rasio DER memiliki rata-rata sebesar -0,2063 dengan standar deviasi 0,66332. Nilai leverage tertinggi (maksimum) sebesar 0,98, sedangkan nilai terendah (minimum) sebesar -1,69. Variabel likuiditas yang dihitung dengan rasio current ratio memiliki rata-rata sebesar 0,4507 dengan standar deviasi 0,53626. Likuiditas tertinggi (maksimum) adalah 1,54, sedangkan nilai terendah (minimum) sebesar -0,50. Kebijakan dividen yang diproksikan dengan DPR yang memiliki rata-rata sebesar 4,0880 dengan standar deviasi 0,28471. Kebijakan dividen tertinggi (maksimum) sebesar 4,60, sedangkan nilai terendah (minimum) sebesar 3,41. 


\section{Uji Normalitas}

Tabel 2. Pengujian Kolmogorov-Smirnov

\begin{tabular}{llr}
\hline \multicolumn{2}{c}{ One-Sample Kolmogorov-Smirnov Test } \\
\hline $\mathrm{N}$ & $\begin{array}{c}\text { Unstandardized } \\
\text { Residual }\end{array}$ \\
Normal Parameters ${ }^{\mathrm{a}, \mathrm{b}}$ & Mean & 34 \\
& Std. Deviation &, 0000000 \\
& &, 17155129 \\
Most Extreme Differences & Absolute &, 147 \\
& Positive &, 078 \\
Test Statistic & Negative & -147 \\
Asymp. Sig. (2-tailed) & &, 147 \\
\hline
\end{tabular}

a. Test distribution is Normal.

b. Calculated from data.

c. Lilliefors Significance Correction.

Uji yang digunakan untuk melihat apakah data tersebut berdistribusi normal atau tidak yaitu menggunakan uji Kolmogorov-Smirnov. Apabila probabilitas asym.sig > 0,05 maka data terdistribusi normal. Berdasarkan hasil uji normalitas menunjukkan besarnya nilai signifikansi Asym. Sig. (2-tailed) sebesar 0,059 > 0,05 maka dapat disimpulkan bahwa data berdistribusi normal.

Uji Multikolinearitas

Tabel 3. Hasil Uji Multikolinearitas

\begin{tabular}{|c|c|c|c|}
\hline \multirow{2}{*}{\multicolumn{2}{|c|}{ Model }} & \multicolumn{2}{|c|}{ Collinearity Statistics } \\
\hline & & \multirow[t]{2}{*}{ Tolerance } & \multirow[t]{2}{*}{ VIF } \\
\hline$\overline{1}$ & (Constant) & & \\
\hline & Kesempatan_Investasi & 847 & 1,180 \\
\hline & Leverage & 173 & 5,766 \\
\hline & Likuiditas & 163 & 6,152 \\
\hline
\end{tabular}

Sumber : Hasil olah data SPPS, 2020

Berdasarkan tabel hasil uji multikolinearitas dapat dilihat bahwa nilai VIF semua variabel berada diantara angka 1 sampai 10. Nilai Varian Inflation Factor (VIF) dari variabel kesempatan investasi sebesar 1,180, variabel leverage sebesar 5,766, dan variabel likuiditas sebesar 6,152. Selain itu, dapat dilihat juga bahwa nilai tolerance dari variabel kesempatan investasi sebesar 0,847 , variabel leverage sebesar 0,173 , dan variabel likuiditas sebesar 0,163 . Sehingga dapat disimpulkan bahwa tidak terjadi masalah multikolinearitas. 


\section{Uji Heteroskedastisitas}

\section{Tabel 4. Hasil Pengujian Glejser}

Coefficients ${ }^{a}$

\begin{tabular}{|c|c|c|c|c|c|c|}
\hline & \multirow[t]{2}{*}{ Model } & \multicolumn{2}{|c|}{$\begin{array}{c}\text { Unstandardized } \\
\text { Coefficients }\end{array}$} & \multirow{2}{*}{$\begin{array}{c}\text { Standardized } \\
\text { Coefficients }\end{array}$} & \multirow[t]{2}{*}{$\mathrm{t}$} & \multirow[t]{2}{*}{ Sig. } \\
\hline & & $\mathrm{B}$ & Std. Error & & & \\
\hline \multirow[t]{4}{*}{1} & (Constant) & 025 & ,073 & & ,337 & ,739 \\
\hline & Kesempatan_Investasi &,- 004 & ,003 &,- 248 & $-1,322$ & 196 \\
\hline & Leverage & ,071 & ,069 & 428 & 1,032 & 310 \\
\hline & Likuiditas & ,045 & ,088 & 218 &, 508 & 615 \\
\hline
\end{tabular}

a. Dependent Variable: Abs_RES

Sumber : Hasil olah data SPSS, 2020

Berdasarkan tabel hasil pengujian glesjer dapat dilihat bahwa nilai signifikan untuk ketiga variabel yaitu kesempatan investasi sebesar 0,739, leverage sebesar 0,196, dan likuiditas sebesar 0,615. Hasil tersebut menunjukkan bahwa nilai signifikan masing-masing variabel independen lebih dari 0,05 maka dapat disimpulkan tidak terjadi gejala heterokedastisitas dalam model regresi.

\section{Uji Autokorelasi}

Tabel 5. Hasil Pengujian Run Test

\begin{tabular}{lr}
\hline \multicolumn{2}{c}{ Runs Test } \\
\hline & $\begin{array}{c}\text { Unstandardize } \\
\text { d Residual }\end{array}$ \\
\hline Test Value $^{\mathrm{a}}$ &,- 02468 \\
Cases < Test Value & 17 \\
Cases >= Test Value & 17 \\
Total Cases & 34 \\
Number of Runs & 15 \\
Z &,- 871 \\
Asymp. Sig. (2-tailed) &, 384 \\
\hline a. Median &
\end{tabular}

Sumber : Hasil olah data SPSS, 2020

Berdasarkan tabel 5 di atas, menunjukkan nilai Asymp. Sig. (2-tailed) sebesar 0,384 yang lebih besar dari 0,05. Maka dapat disimpulkan bahwa hasil uji autokorelasi berdasarkan Uji run test tidak terdapat gejala atau masalah autokorelasi. 


\section{Analisis Regresi Linear Berganda}

Tabel 6. Hasil Uji Regresi Linier Berganda

\begin{tabular}{|c|c|c|c|c|c|c|}
\hline & \multirow[t]{2}{*}{ Model } & \multicolumn{2}{|c|}{$\begin{array}{l}\text { Unstandardized } \\
\text { Coefficients }\end{array}$} & \multirow{2}{*}{$\begin{array}{l}\text { Standardize } \\
\text { d } \\
\text { Coefficients }\end{array}$} & \multirow[t]{2}{*}{$\mathrm{t}$} & \multirow[t]{2}{*}{ Sig. } \\
\hline & & B & Std. Error & & & \\
\hline \multirow[t]{4}{*}{1} & (Constant) & 4,500 & 120 & & 37,573 & 000 \\
\hline & Kesempatan_Investasi & ,007 & ,005 & 171 & 1,433 & 162 \\
\hline & Leverage &,- 252 & 113 &,- 586 & $-2,219$ & 034 \\
\hline & Likuiditas &,- 639 & ,145 & $-1,203$ & $-4,410$ & ,000 \\
\hline
\end{tabular}

Sumber : Hasil olah data SPPS, 2020

Berdasarkan tabel IV. 11 di atas, dapat disusun persamaan regresi sebagai berikut:

$\mathrm{Y}=4,500+0,007 \mathrm{X}_{1}-0,252 \mathrm{X}_{2}-0,639 \mathrm{X}_{3}+e$

\section{Uji koefisien determinasi $\left(R^{2}\right)$}

Tabel 7. Hasil Uji Koefisien Determinasi

\begin{tabular}{lrrrrr}
\hline \multicolumn{6}{c}{ Model Summary $^{\mathbf{b}}$} \\
\hline Model & $\mathrm{R}$ & R Square & $\begin{array}{c}\text { Adjusted R } \\
\text { Square }\end{array}$ & $\begin{array}{l}\text { Std. Error of } \\
\text { the Estimate }\end{array}$ & $\begin{array}{c}\text { Durbin- } \\
\text { Watson }\end{array}$ \\
\hline 1 &, $798^{\mathrm{a}}$ &, 637 &, 601 &, 17992 & 1,236 \\
\hline
\end{tabular}

a. Predictors: (Constant), Likuiditas, Kesempatan_Investasi, Leverage

b. Dependent Variable: Kebijakan_Dividen

Sumber : Hasil olah data SPSS, 2020

Berdasarkan tabel IV. 12 di atas, menunjukkan bahwa besarnya Adjusted R Square adalah 0,601, hal ini berarti $60,1 \%$ kebijakan dividen dipengaruhi oleh variabel kesempatan investasi, leverage, dan likuiditas. Sedangkan sisanya 39,9\% dipengaruhi oleh variabel lain yang belum diteliti dalam penelitian ini.

\section{Uji Signifikansi Parameter Individual (Uji Statistik $t$ )}

Tabel 8. Hasil Uji t

\begin{tabular}{|c|c|c|c|c|c|c|}
\hline & \multirow[t]{2}{*}{ Model } & $\begin{array}{r}\text { Unstan } \\
\text { Coef }\end{array}$ & $\begin{array}{l}\text { dardized } \\
\text { icients }\end{array}$ & $\begin{array}{c}\text { Standardize } \\
\mathrm{d} \\
\text { Coefficients } \\
\end{array}$ & \multirow[t]{2}{*}{$\mathrm{t}$} & \multirow[t]{2}{*}{ Sig. } \\
\hline & & B & Std. Error & Beta & & \\
\hline \multirow[t]{4}{*}{1} & (Constant) & 4,500 & ,120 & & 37,573 & , 000 \\
\hline & Kesempatan_Investasi & ,007 & ,005 & 171 & 1,433 & 162 \\
\hline & Leverage &,- 252 & 113 &,- 586 & $-2,219$ & ,034 \\
\hline & Likuiditas &,- 639 & , 145 & $-1,203$ & $-4,410$ &, 000 \\
\hline
\end{tabular}

Sumber : Hasil olah data SPSS, 2020

Berdasarkan tabel hasil uji t di atas, nilai signifikan variabel Kesempatan Investasi 0,000 > 0,05, t 0,009 = $\mathbf{H}_{\mathbf{1}}$ ditolak; nilai signifikan variabel Leverage $0,001<0,05, \mathrm{t}-0,900=\mathbf{H}_{\mathbf{2}}$ diterima ; nilai signifikan variabel Likuiditas $0,000<0,05, \mathrm{t}-1,422=\mathbf{H}_{3}$ ditolak 


\section{Uji Statistik F}

Tabel 9. Hasil Uji Statistik F

\begin{tabular}{llrrrrr}
\hline \multicolumn{7}{c}{ ANOVA $^{\text {a }}$} \\
\hline \multirow{2}{*}{ Model } & Sum of & df & Mean Square & F & \multicolumn{1}{c}{ Sig. } \\
\hline 1 & Squares & & & & & \\
& Regression & 1,704 & 3 &, 568 & 17,543 &, $000^{\mathrm{b}}$ \\
& Residual &, 971 & 30 &, 032 & & \\
& Total & 2,675 & 33 & & &
\end{tabular}

a. Dependent Variable: Kebijakan_Dividen

b. Predictors: (Constant), Likuiditas, Kesempatan_Investasi, Leverage

Sumber : Hasil olah data SPSS, 2020

Berdasarkan tabel hasil uji F, diperoleh nilai tingkat signifikansi 0,000 yang menunjukkan < 0,05. Maka dapat disimpulkan bahwa secara bersama - sama variabel kesempatan investasi, leverage, dan likuiditas berpengaruh signifikan terhadap kebijakan dividen pada perusahaan yang tercatat di Jakarta Islamic Index tahun 2015 sampai dengan tahun 2018.

\section{Pengaruh Kesempatan Investasi terhadap Kebijakan Dividen}

Kesempatan investasi merupakan posisi perusahaan saat mendapatkan dana yang diperoleh dari profit perusahaan yang akan digunakan untuk mendanai kegiatan investasi, sehingga terjadi perbedaan antara kepentingan pemegang saham perusahaan dengan manajemen perusahaan. Manajemen perusahaan lebih memilih memanfaatkan peluang investasi yang ada saat itu untuk mendanai kegiatan investasi yang dapat memberikan manfaat dimasa yang akan datang. Ketika perusahaan memiliki dana untuk investasi kembali belum tentu perusahaan tersebut akan membagikan dividen kepada para pemegang saham atau investor. Sebab ada hal yang harus diperhatikan baik itu internal perusahaan seperti kegiatan operasional perusahaan maupun eksternal perusahaan seperti untuk melakukan kegiatan investasi.

Kesempatan invesatasi tidak mempengaruhi besar kecilnya pembagian dividen pada suatu perusahaan. Sehingga, tidak ada keterkaitan antara kedua variabel tersebut. Hasil penelitian ini tidak sesuai dengan teori keagenan (agency theory), karena pada teori tersebut mendasarkan pada hubungan antara pemegang saham dengan manajemen perusahaan. Hubungan yang dimaksud ialah hubungan timbal balik antara kedua belah pihak, misalnya saat pemegang saham menanamkan modal pada suatu perusahaan, perusaan memberikan imbal balik berupa pembagian dividen. Sedangkan hasil penelitian menunjuukan bahwa kesempatan investasi tidak memiliki pengaruh terhadap kebijakan dividen. Artinya tidak ada keterkaitan atau hubungan antara pihak pemegang saham dengan pihak manajemen.

\section{Pengaruh Leverage terhadap Kebijakan Dividen}

Leverage atau hutang jangka panjang diikat oleh sebuah perjanjian utang untuk melindungi kepentingan kreditor. Kreditor biasanya membatasi pembayaran dividen, pembelian saham beredar, dan penambahan utang untuk menjamin pembayaran pokok hutang dan bunga. Apabila kegiatan operasional perusahaan didanai dengan hutang yang besar maka perusahaan juga akan memiliki risiko yang semakin besar terhadap hutang tersebut. Hal tersebut akan membuat manajemen perusahaan lebih mendahulukan dan mengutamakan 
melunasi hutangnya menggunakan laba daripada laba tersebut dibagikan sebagai bentuk dividen.

Hasil penelitian ini sesuai dengan teori keagenan yang bersangkutan dengan masalah pembagian risiko (risk problem). Perbedaan risiko yang dilihat dari dua sudut pandang yang berbeda yaitu pihak pemegang saham dan pihak manajemen perusahaan bahwa manajemen perusahaan lebih mengutamakan dan melindungi kreditor, karena kreditor merupakan pihak yang meminjami dana untuk keberlangsungan hidup perusahaan. Dana yang diperoleh tersebut digunakan untuk kegiatan operasional perusahaan, pembangunan, dan lainnya. Kepentingan kreditor diutamakan agar pihak kreditor kedepannya tetap meminjami dana bagi perusahaan. Sedangkan, risiko pemegang saham dalam masalah pengendalian outcome yaitu pemegang saham harus siap saat perusahaan tidak membagikan dividennya secara stabil.

\section{Pengaruh Likuiditas terhadap Kebijakan Dividen}

Semakin tinggi nilai likuiditas pada suatu perusahaan maka perusahaan itu dianggap baik dan perusahaan mampu membayar hutang lancar yang akan segera jatuh tempo dengan aktiva lancar yang dimilikinya. Peningkatan rasio tersebut berarti menandakan bahwa kas perusahaan juga meningkat. Namun, terlalu tingginya nilai likuiditas memungkinkan perolehan laba yang kecil, karena kas yang tinggi tersebut tidak digunakan untuk kegiatan operasional yang efisiensi. Seperti misalnya pengolahan tenaga kerja, mesin, peralatan tidak dilakukan secara optimal menggunakan kas yang ada. Sehingga dari ketidak efisiensinya kas tersebut mengakibatkan laba yang diperoleh perusahaan kecil. Semakin kecil laba yang diperoleh perusahaan akan berdampak pada menurunnya pembayaran dividen bagi investor. Kas yang dimiliki oleh perushaan yang menjadi sampel dalam penelitian ini tidak digunakan secara maksimal dan efisiensi. Kas yang tinggi tersebut akan menambah tingkat laba dalam laporan keuangan perusahaan. Namun, kenyataanya laba yang tinggi itu tidak dibagikan kepada para pemegang saham sebagai bentuk dividen. Dalam kasus ini, pemegang saham berkewajiban melakukan pengawasan (monitoring) terhadap pihak manajemen (agen). Hal tersebut sesuai dengan peneyelesaian masalah apabila terjadi agency problem antara pihak pemegang saham (principal) dan pihak manajemen (agen).

\section{Penutup dan Saran}

\section{Kesimpulan}

Berdasarkan hasil dan pembahasan dan penelitian pengaruh kesempatan investasi yang diproxy-kan dengan CAPBVA, leverage yang diproxy-kan dengan DER, dan likuiditas yang diproxy-kan dengan CR pada perusahaan yang tercatata di Jakarta Islamic Index periode 20152018 yang telah dilakukan, maka dapat disimpulkan sebagai berikut :

1. Kesempatan Investasi $\left(X_{1}\right)$ tidak memiliki pengaruh yang signifikan terhadap kebijakan dividen pada perusahaan yang tercatat di Jakarta Islamic Index periode 2015 sampai dengan 2018 yang menunjukkan bahwa perusahaan yang memiliki kesempatan investasi yang tinggi akan memilih menggunakan kesempatan tersebut untuk berinvestasi, sehingga kebijakan dividen tidak diperhatikan.

2. Leverage $\left(\mathrm{X}_{2}\right)$ berpengaruh negatif signifikan terhadap kebijakan dividen pada perusahaan yang tercatat di Jakarta Islamic Index periode 2015 sampai dengan 2018 yang menunjukkan 
bahwa semakin tinggi nilai leverage maka akan berdampak pada rendahnya pembagian dividen.

3. Likuiditas (X3) berpengaruh negatif signifikan terhadap kebijakan dividen pada perusahaan yang tercatat di Jakarta Islamic Index periode 2015 sampai dengan 2018 yang menunjukkan bahwa semakin meningkatnya nilai likuiditas maka akan berdampak pada rendahnya dividen yang akan dibagikan kepada para investo

\section{Saran}

1. Bagi Pihak Investor

Bagi pihak investor yang akan menginvestasikan dananya pada perusahaan yang memiliki pendapatan/laba yang tinggi khususnya pada perusahaan yang masuk di Jakarta Islamic Index (JII), disarankan untuk lebih cermat dalam menganalisa dan memperhatikan kinerja perusahaan sehingga tidak terpengaruh oleh peningkatan pembayaran dividen yang semu. Tidak semua perusahaan yang kesempatan investasinya besar, memberikan dividen yang besar. Begitupun dengan likuiditas, apabila likuiditas perusahaan tinggi juga tidak memungkinkan bahwa pembagian dividen akan tinggi.

2. Bagi Penelitian Selanjutnya

Bagi penelitian selanjutnya, diharapkan penelitian ini dapat menjadi acuan untuk melakukan penelitian berikutnya dengan memperluas ruang lingkup penelitian dan menambah variabel independen lain yang diduga dapat mempengaruhi kebijakan dividen yang belum diteliti dalam penelitian ini. 


\section{Referenasi}

Abdalloh, I. (2018). Pasar Modal Syari'ah. PT Elex Media Komputindo. Jakarta.

Arilaha, M. A. (2009). Pengaruh free cash flow, profitabilitas, likuiditas, dan leverage terhadap kebijakan dividen. Jurnal keuangan dan Perbankan, 13(1), 78-87.

Baramuli, D. N. (2016). Pengaruh Likuiditas dan Profitabilitas terhadap Devidend Payout Ratio pada Top Bank di Indonesia (BRI, Bank Mandiri, BNI dan BCA). EFISIENSI, 16(3), 356-366.

Dewi, D. M. (2016). Pengaruh likuiditas, leverage, ukuran perusahaan terhadap kebijakan dividen tunai dengan profitabilitas sebagai variabel intervening. Jurnal bisnis dan ekonomi, 23(1), 12-19.

Ghozali, I. (2013). Aplikasi Analisis Multivariate dengan Program SPPS. EdisiKetujuh. Universitas Diponegoro. Semarang.

Ginting, S. (2018). Pengaruh Likuiditas, Profitabilitas. Dan Leverage Terhadap Kebijakan Deviden Pada Perusahaan Lq45 Yang Terdaftar Di Bursa Efek Indonesia Periode 20122016. Jurnal Wira Ekonomi Mikroskil: JWEM, 8(2), 195-204.

Hery. (2012). Analisis Laporan Keuangan. Cetakan Pertama. PT Bumi Aksara Jakarta.

Indriyo, G., \& Basri, H. (2002). Manajemen Keuangan, edisi keempat. BPFE Yogyakarta.

Kasmir. (2010). Pengantar Manajemen Keuangan. Edisi Pertama, Cetakan ke-1. Prenada Media Group. Jakarta.

Marpaung, E. I., \& Hadianto, B. (2009). Pengaruh Profitabilitas dan Kesempatan Investasi terhadap Kebijakan Dividen: Studi Empirik pada Emiten Pembentuk Indeks LQ45 di Bursa Efek Indonesia. Jurnal Akuntansi, 1(1), 70-84.

Masril, M. (2017). Pengaruh Likuiditas, dan Size Terhadap Kebijakan Dividen dengan Laba Bersih Sebagai Moderate. Jurnal Wira Ekonomi Mikroskil: JWEM, 7(2), 181-190.

Mawarni, L. F. I., \& Ratnadi, N. M. D. (2014). Pengaruh Kesempatan Investasi, Leverage,dan Likuiditas pada Kebijakan Dividen Perusahaan Manufaktur yang Terdaftar di BEI. EJurnal Akuntansi Universitas Udayana 9(1), 200-208.

Nurhayati, M. (2013). Profitabilitas, likuiditas dan ukuran perusahaan pengaruhnya terhadap kebijakan dividen dan nilai perusahaan sektor non jasa. Jurnal Keuangan \& Bisnis Program Studi Magister Manajemen Sekolah Tinggi Ilmu Ekonomi Harapan, 5(2), 144-153.

Perdana, B. C. (2018). Analisis Pengaruh Likuiditas, Leverage, dan Profitabilitas Terhadap Kebijakan Dividen Pada Sektor Industri Manufaktur di BEI. Majalah Ekonomi, 23(1), 3752. 
Pradana, S. W. K., \& Sanjaya, I. P. S. (2014). Pengaruh Profitabilitas, Free Cash Flow, dan Investment Opportunity Set Terhadap Dividend Payout Ratio (Studi Empiris pada Perusahaan Perbankan yang terdaftar di BEI). Jurnal Keuangan dan Perbankan, 21(1) 21(1), 133-124.

Riskilia Fistyarini, K. (2015). Pengaruh Profitabilitas, Ios Dan Leverage Terhadap Kebijakan Dividen Tunai Dengan Dimoderasi Likuiditas. Accounting Analysis Journal, 4(2), 1-8.

Riyanto, B. (2001). Dasar - Dasar Pembelajaran Perusahaan. BPFE. Yogyakarta.

Salim, J. (2010). Bisa Menjadi Miliader dalam Tempo Singkat Rahasianya? Harus Tahu Kapan Bit and Ask. PT Elex Media Komputindo. Jakarta.

Saputro, A. A., \& Hindasah, L. (2015). Pengaruh Kebijakan Pendanaan, Deviden dan Profitabilitas Perusahaan terhadap Set Kesempatan Investasi (IOS). Journal of Accounting and Investment, 8(1), 58-71.

Sari, N., Ayu, K., \& Sudjarni, L. K. (2015). Pengaruh likuiditas, leverage, pertumbuhan perusahaan, dan profitabilitas terhadap kebijakan dividen pada perusahaan manufaktur di BEI. E-Jurnal Manajemen Universitas Udayana, 4(10), 3346- 3374.

Sartono, A. (2001). Manajemen Keuangan Teori dan Aplikasi. Edisi Keempat. Fakultas Ekonomi UGM Yogyakarta.

Sartono, A. (2008). Manajemen Keuangan Teori dan Aplikasi. Edisi Keempat. BPFE. Yogyakarta.

Suharli, M. (2007). Pengaruh Profitability Dan Investment Opportunity Set Terhadap Kebijakan Dividen Tunai Dengan Likuiditas Sebagai Variabel Penguat (Studi Pada Perusahaan Yang Terdaftar Di Bursa Efek Jakarta. Jurnal Akuntansi dan Keuangan, 9(1), 917.

Tarwiyah, L. (2018). Pengaruh Investment Opportunity Set, Leverage, Profitabilitas dan Likuiditas terhadap Kebijakan Dividen (Studi pada sektor Industri Barang Konsumsi Yang Terdaftar di Bursa Efek Indonesia Periode 2014-2016. Sripsi. Program Studi Akuntansi UIN Maula Malik Ibrahim. Malang.

Wahyuni, N. L. A., Zukhri, A., \& Nuridja, I. M. (2015). Pengaruh Profitabilitas Dan Likuiditas Terhadap Besarnya Dividen Yang Dibagikan Kepada Pemegang Saham Pada Perusahaan Manufaktur Yang Terdapat Di Bei. Jurnal Pendidikan Ekonomi Undiksha, 5(1).

Weston, J. F., \& Coppeland, T. E. (1996). Managerial Finance 9th ed. The Dryden Press. Terjemahan Wasana A. J, dan Kibrandoko. 1997. Manajemen Keuangan. Edisi revisi. Binarupa Aksara. Jakarta .

Widiotmodjo, S. (2005). Seri Membuat Uang Bekerja Untuk Anda Cara Sehat Investasi di Pasar Modal Pengantar Menjadi Investor Profersional. PT Elex Media Komputindo. Jakarta. 
Jurnal Ilmiah Mahasiswa Manajemen, Bisnis dan Akuntansi 2(4) Agustus 2020

Widiotmodjo, S. (2015). Pengetahuan Pasar Modal untuk konteks Indonesia. PT Elex Media Komputindo. Jakarta.

Yurinawati, W., \& Andayani. (2017). Pengaruh kinerja keuangan, ukuran perusahaan dan jaminan aset terhadap kebijakan dividen. Jurnal Ilmu dan Riset Akuntasi 6(9). 